\title{
UDC 004.942:656.61.052 \\ AUTOMATED IDENTIFICATION OF AN OPERATOR ANTICIPATION ON MARINE TRANSPORT
}

Nosov P. S. - PhD, Associate Professor of Navigation and electronic navigation systems Department, Kherson State Maritime Academy, Ukraine.

Popovych I. S. - Dr. Sc., Professor of the Department of General and Social Psychology, Kherson State University, Ukraine.

Cherniavskyi V. V. - Dr. Sc., Professor, Rector of Kherson State Maritime Academy, Ukraine.

Zinchenko S. M. - PhD, Senior Lecturer of Ship Handling Department, head of the laboratory of electronic simulators, Kherson State Maritime Academy, Ukraine.

Prokopchuk Y. A. - Dr. Sc., Associate Professor, Leading Researcher, Department of systems analysis and control problems, Institute of Technical Mechanics, National Academy of Sciences, Ukraine.

Makarchuk D. V. - PhD, Senior Lecturer of Ship Handling Department, Kherson State Maritime Academy, Ukraine.

\section{ABSTRACT}

Context. The article discusses approaches to anticipation identification being an essential part of the decision-making process done by the operator by using the example of a sea captain in ergatic systems of critical infrastructures in the sea transport management. The mentioned above aspect of anticipation of operators can be regarded as being a complex form of human-machine interaction and, certainly, claims for further elaboration of information and tools to be used.

Objective. The way to approach development is taken as being based on an information analysis of the full range of trajectories of decision-making by operators at the time of performing complex multi-stage actions. These items are rooting out of their adopted strategy of human-machine interaction. Besides, it leads to the formation of a metric being able to algorithmically represent the enormous number of variants. It can be done taking into account conditions of combinatorial representation in terms of the geometric theory of groups on the Cayley graph.

Method. Being a part of the approach elaboration the having been obtained during the analysis of the database of navigation simulators mathematical model of experimental data collecting and processing succeeded to be constructed. To confirm the formalalgorithmic approach a simulation was challenged to be carried out helping to form the trajectory of the operator's decision making in critical situations. It was felicitously performed basing on the three-factor ERO-AEA-EAPI model. Thus, the algebraic and software representation of the metric decision space is noticed to uncover approximate complex human-machine interactions in uncertain environments. As a result, the converting process of data of the main subject of critical infrastructure (i.e. the operator) into knowledge is able to be coped with. In addition, factors possible to be gauged in the proposed metric are able to be uncovered.

Results. In order to carry out the feasibility assessment of the developed approach as well as formal-algorithmic ones, an experiment was performed by using the Navi Trainer 5000 navigation simulator (NTPRO 5000). During having one of the most troublesome operations i.e. mooring we wanted the server data to be analyzed. As a result, data about anticipation being shaped as triangular constructs in the quasi-isometric space of Cayley graph is reported to have been obtained. The automated neural networks being used for result obtaining led to delivering of the possibility to get multiple data regression and to analyze the relationships of many independent variables. It is considered to be clear evidence due to having found out results of scattering and reliability diagrams.

Conclusions. The having been presented in the investigations formal-algorithmic approach together with the developed software tools and the approaches of converting data into knowledge about operator anticipation are said to embrace the possibility to classify and to identify individual decision-making strategies when managing a vessel and to predict the likelihood of poor consequences. With regarding to the cogency of the proposed approach and models these issues happen to have been successfully justified by means of the automated processing of experimental data.

KEYWORDS: decision support systems; knowledge identification systems; operator model; computer navigation simulators; management of risks; human factor analysis; automated control systems.

\section{ABBREVIATIONS}

DSS is a decision support system;

NTPRO 5000 is a navigation simulator "Navi Trainer 5000";

ARPA is an automatic radar plotting aid;

AIS is an Automatic Identification System;

ECDIS is an Electronic Chart Display and Information System;

RADAR is a radar station;

ERO is an expected results of operations;

AEA is an anticipated event awareness;

EAPI is an expected attitude towards participants in interpersonal interaction.

\section{NOMENCLATURE}

$X_{g}, Y_{g}$ is a metric space;

$d_{x_{g}}, d_{y_{g}}$ is a space metric;

$\delta$ is a geodesic neighborhood;

$x^{\prime}$ is a signs of anticipation;

$\left(X_{t}^{*}\right) \alpha$ is an influence of new data;

$W_{t}$ is a conditions;

$Z$ is a mooring task;

$a_{t}$ is a detalization;

$b_{t}$ is a generalization;

$f$ is a quasimetric attachment; 
$c_{g}, k$ are constants;

$a$ is a maneuvering with a change in the operating mode of the main engine;

$b$ is a shift pen rudder;

$c$ is a change of the operating mode of the thruster;

$p$ is a point located on the geodetic segment;

$c_{a}$ is a bounded quasi-isometric mapping;

$x_{g}, y_{g}, z_{g}$ are vertexs;

$\gamma$ is a geodesic segment (path);

$r$ is a geodesic segment length;

$S_{i}$ is an area of the flat;

$(M, d)$ is a metric space;

$a_{g}, b_{g}$ are an any two points on sides;

$x$ is a situation;

$B_{t}(x)$ is an action plan (detail);

$C_{t}(x)$ is a summarizing data;

$\{$ Ind $\}$ is a forms inductors;

$D_{j}$ is an information domains;

$P(x, z)$ is a predicate;

$A(x)$ is a set of probable solutions;

$\Omega_{t}$ is a set of rules is primarily formed;

$H_{t}$ is a data generation conditions;

$\left\{S^{*}\right\} \alpha$ is a favorable treatment;

$U_{t}$ is a possibility of having options;

$e$ is an activity of captain;

$V$ is an objective reality, regularity;

$E Z$ is an energy and motivation of the captain;

$\tau$ is a basis of the tests;

$\{\Xi\}$ is a destined for observing the constructing domain digraphs experience;

$\theta G$ is a set of elementary operations;

$\{A g\}$ is a micro social environment limited.

\section{INTRODUCTION}

It goes without saying that the processes involving human-machine interaction in ergatic systems are sure to have always been a crucial field directly affecting the final result. In the contemporary critical infrastructures with an operator having in the information circuit, under the great security influence these processes are to be drawn attention to as reflecting great interest [1]. Modern information technologies demonstrating competencies in finding solutions aimed at ensuring the safety of ergatic systems are using the example of maritime transport to a small degree. The human factor manifestations are named to have always been main contributors to a significant increase of the likelihood of faulty situations.

Signaling is usually made in the form of a warning directive to the vessel crossing dangerous areas or approaching target vessels (Fig. 1), obstacles or dangerous isobaths so, therefore, a safety circuit is mandatory to be used (Fig. 2.) [2]

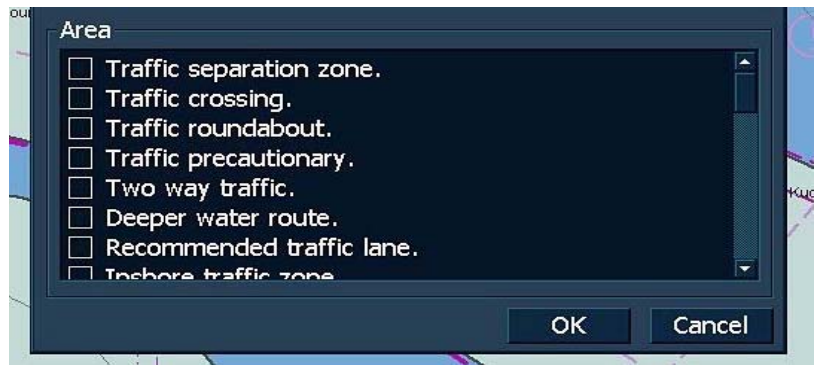

Figure 1 - Identification of hazardous areas of navigation

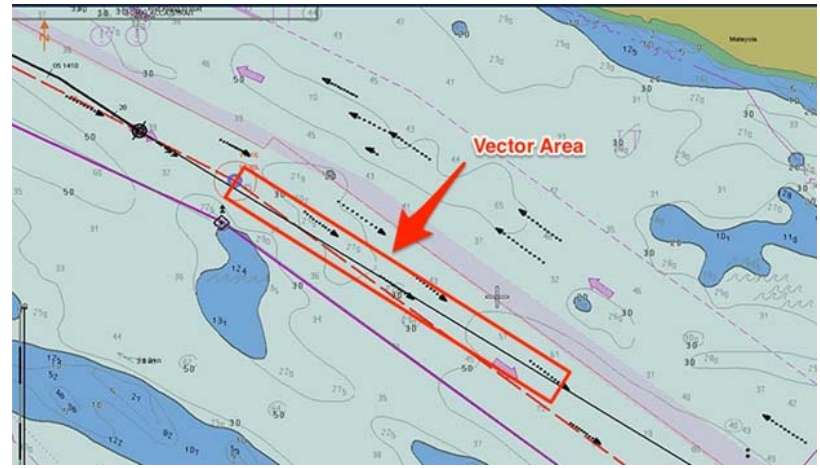

Figure 2 - Display of the ship safety frame

The operator himself is able to choose and even create his own circuits for having being alerted by the security system experience. The ECDIS system is noticed to be having enough tools for automated security settings by using electronic navigation charts. In addition, other troubles to be mentioned happening like signaling due to having problems in the engine room, rough weather conditions can be successfully coped with. At the same time, on the opposite, there is little evidences speaking about tools that are involved into taking into account the operator's response to the data stream and signals of navigation devices. Selecting highly qualified operators might be a key issue in the attempt to solve this problem but the complication to be paid special attention to is not being aware of the having been used shaping experience [3]. Besides, when constructing automated systems frame aiming to improve security level in this meaning, it is important to be focused on the "average" operator experience and qualification. Nowadays they tend to be more than $70 \%$ of the total. Previously having been implemented reviews made us face the challenge of highlighting the questions of having negative influence of individual groups of factors on the operator's behavior pattern, concentration of attention and communication features in the group [4-6].

However, questions related to the planning of the trajectory of actions and the expectation of a future result due to their individual formation pattern are still remained to be not enough discussed. Certainly, in order to obtain results in this field it is considered to be complicated to determine the approaches for identifying information signs and signals. Nevertheless, exactly these issues make 
it possible to build automated means for improving safety in maritime transport.

Thus, the problem is highlighted reflecting having the negative manifestation of operator anticipation as a component of the human factor. Analysis of accidents as well as work with cadets during training drills at navigation simulators at the Kherson State Maritime Academy (Ukraine) proves the established hypothesis of anticipation being decisive cornerstone in making decisions correct beyond any doubt. This pattern of human factor behavior especially manifests itself in the following conditions: an operator has already had experience, for example, captain or his first assistant, or he navigates in the water area he is quite get acquainted with. It must be emphasized that avoiding the negative manifestation of anticipation is highly likely to happen by automated means for its identification and manifestations in dynamics relative to each operator.

Hence, the object of research frames the question of the process of automated identification of anticipation of operators while performing complex maneuvers in the management of sea transport.

The subject of the study is models and algorithms that implement the process of automatic identification of operator anticipation in critical and difficult-to be-

The purpose of the study is taken to be to introduce and promote a mathematical and algorithmic justification for the development of a module of a DSS in order to identify the beginning point of operator's anticipation and its dynamics in the presented metric to meet or to improve safety level in maritime transport.

The purpose of the article is chosen to be the applying special purpose solution method embracing the following problems:

1. To specify a formal approach for the formation of a functionally defined space $Y_{g}$ with a metric $d_{y_{g}}$, to display the manifestations of anticipation of the operator.

2. To approximate the decision-making process made by the operator basing on the three-factor model EROAEA-EAPI in the form of a geometrically defined trajectory on the surface of Cayley graph $X_{g}$ with a metric $d_{x_{g}}$,

with an intention to synchronize the data of the Transas navigation simulator NTPRO 5000 and the encoded trajectory.

3. To determine extrema on the Cayley graph able to convert the surface to quasi-isometric item and allowing to obtain the distortion value in the form $\delta$ of aneighborhood on the geodesic triangle ERO-AEA-EAPI. According to carrying out experience the operator's anticipation centers seem to be activated and seen.

4. To conduct an experiment using the Transas navigation simulator NTPRO 5000. It would be involved into having the possibility of automatically manner build the triangular space of the ERO-AEA-EAPI based on the results of the navigation tasks and identify the centers, magnitude and dynamics of operators' anticipation. predicted situations.

5. To formally introduce an information model of the formation of operator anticipation and identify signs of anticipation $x^{\prime}$, as well as the influence of new data $\left(X_{t}^{*}\right) \alpha$ on its manifestation in the form of a thin section $X_{t+1}^{*} \quad$ under the conditions $W_{t}, \quad Z$ and psychophysiological parameters of the operator.

6. To develop a model of the dynamics of the centers of anticipation of operators in the form of a ShukhartDeming spiral cycle from detalization $a_{t}$ to generalization $b_{t}$ and back $a_{t+1}$. This issue will be able to provide the possibility of having negative manifestations of anticipation predicted in a discrete form.

7. To construct a multiple regression using the experimental data of the trajectories of decision-making by operators by means of automated neural networks. Further actions proposing to be taken include their training process to be involved with an aim to organize the effective work of DSS and, as a result, to identify the negative manifestation of anticipation in maritime transport operators.

Hence, the best tackle of current spoken above challenges means dealing with getting the opportunity to succeed in achieving problem solution of identification and prediction of anticipation of operators in maritime transport. The allocated experimental data is intended to deliver further probable development of DSS with a goal of creating and enhancing more sustainable safety environment in maritime transport by diminishing the negative manifestations of the human factor.

\section{PROBLEM STATEMENT}

The research dedicated to the operator mental states map designing in rough environment reflected the idea of having identified points on its surface mattered. It must be noted that each operator is about to have this surface functioning in up-to individual mode due to its basing on personal preferences and behavior patterns as well as on a complex system of social expectations. From the first point of view, the base points of the surface are not noticed to be connected with each other. However, further reconsideration can propose getting the opportunity of building connections by selecting construction elements using terminology of the theory of geometric groups [7].

Thereby, construction elements form segments and the last ones tend to build a geometric structure i.e. functionally defined space. Consequently, the points connected in space form a metric by the help of the given distances between them. Taking into consideration the fact of having all points of the obtained space $Y_{g}$ with metric $d_{y_{g}}$, included in the primary Cayley graph $X_{g}$ with metric $d_{x_{g}}$, the conclusion worth taking is that this metric is induced. So, these points will certainly limit the primary Cayley graph, convert it to the induced pseudo-metric where the points are connected by geodesic segments.

It is vividly seen that for the particular person mental state of being under the influence of his social expectation (C) Nosov P. S., Popovych I. S., Cherniavskyi V. V., Zinchenko S. M., Prokopchuk Y. A., Makarchuk D. V., 2020 DOI 10.15588/1607-3274-2020-3-15 
factors geometric structures will be shaped as a quasimetric attachment $f$ in the form of $f: X_{g} \rightarrow Y_{g}$, if

$$
d_{x_{g}} \quad d_{y_{g}}
$$

$\exists k, c \forall x_{g}, y_{g} \in X_{g}$. To meet this issue requirements for the validity that the distance between the points of the spaces $X_{g}$ and $Y_{g}$ can only change linearly must be observed. This condition delivers the opportunit to save the metric of the primary Cayley graph:

$$
\begin{aligned}
& d_{y_{g}}\left(F\left(x_{g}\right), F\left(y_{g}\right)\right) \ldots \Rightarrow d_{y_{g}}\left(f\left(x_{g}\right), f\left(y_{g}\right)\right) \leq \\
& \leq k d_{x_{g}}\left(x_{g}, y_{g}\right)+c_{g} \Rightarrow \frac{d_{x_{g}}\left(x_{g}, y_{g}\right)}{k}-c_{g} \leq \\
& \leq d_{y_{g}}\left(f\left(x_{g}\right), f\left(y_{g}\right)\right) \leq k d_{x_{g}}\left(x_{g}, y_{g}\right)+c_{g} .
\end{aligned}
$$

Moreover, the nature of this dependence is quasiisometric one because the distance between the points $f\left(x_{g}\right)$ and $f\left(y_{g}\right)$ varies linearly depending on the indicated above constants $c_{g}$ and $k$.

Suppose the application of the proposed approach to the formation of space of social expectations of the individual basing on the results of the research made by Professor I. Popovych at al. [8]. His inquiry suggests a threefactor model to be used consisting of the following areas:

a) ERO; b) AEA; c) EAPI.

Being guided by the mentioned above options, the conclusion can be drawn that the personality while being involved into carrying out activities is basing mostly on three strategies causing definite deeds. Thereby, his social expectations might be founded on these three parallel directions and superimposed on the trajectory of action.

\section{LITERATURE REVIEW}

The research problems are rooted out from the contradictions existing between the needs for automated identification of operator behavior motives in ergatic systems and the capabilities of navigation information systems [9]. In having been studied inquiries related to these issues scientific researches tend to get risk assessment by mathematical processing of the parameters of the information model of the vessel and its dynamics in the water area [10-12]. Others are focused mainly on the enhancement of information tools for the analysis of physiological characteristics of sea transport operators [13, 14]. At the same time, the decision support systems questions can not be avoided as being essential in facilitating safety marine environment reducing the human factor of the operator by analyzing the decisions made during holding humanmachine interaction [15-18]. Furthermore, the task of identifying the manifestations of the human factor itself can be found as being much more problematic one in comparison with ordinary work performed with signals and data from navigation devices RADAR, ARPA, AIS, ECDIS, etc. In the meantime, the deliberate relevance of such investigation is noticed to be expending greatly thanks to automated systems being involved. To some extent, this practice let them respond to manifestation of the negative human factor by automatical diverging in the principles of E-navigation [19, 20].

Contemporary approaches to the sustainable development of automated and intelligent systems are more and more involved into facing challenges to respond the need for undertaking thorough analysis of operator action planning $[21,22]$.

Nevertheless, well-known widely-spread literature is unable to deliver references to efficient automated systems capable of carrying out identification of operator anticipation manifestations as an indicator of the strategy of decisions made in ergatic systems of maritime transport.

\section{MATERIALS AND METHODS}

There is the hypothesis that due to the psychological characteristics of the individual at each interval (stage) of the trajectory of his activity one factor-direction is considered to act as a dominan one, being dominant. Moreover, each fragmented trajectory of human activity has three dominants in each direction factor, thereby, forming a triangular structure having non-trivial individualpersonality properties. They turn out to have scientific and practical significance for the development of the methodology of social expectations of the individual.

For the sake of confirming this hypothesis a simulation of the trajectory of a person's behavior in critical situations is supposed to be performed. One peculiarity is to be made is that independent decision making is required to be based on the three-factor model of EROAEA-EAPI.

Suppose, as a modeling environment critical infrastructure (for example, maritime transport) would be chosen to be spoken about and as an operator, a watch assistant of the captain or captain. Besides, imagine, the environment where the vessel will be operating and maneuvering is said to be one of the most complicated ones (coming up to the pier and mooring operation). To completely satisfy and meet the requirements such options as experience and professional skills of senior assistant of a captain or other higher positions must be taken into consideration.

When constructing the Cayley graph the three axes $a$, $b, c$ would be proposed to be used basing on the reasons that when mooring combinations of control actions rests on three main types of maneuvers:

$a$ - maneuvering with a change in the operating mode of the main engine;

$b$ - shift pen rudder;

$c$ - change of the operating mode of the thruster.

As a rule, taking into account huge number of external and internal factors influencing on, the captain gets used to being guided by combinations of basic maneuvers monitoring the situation in real time mode. Gained experience and mind-motor skills are able to be highly likely the most influential factors on choosing the particular strategy. These items which brings an additional effect that polar influences the final result of the maneuver. 
Thus, to identify the path of the skipper's actions a metric space is proposed to be constructed. It would definitely take into account the entire spectrum of options for the those actions in the context of a three-factor model in the form of a Cayley graph basing on the geometric theory of groups.

It must be underlined that this graph, according to the axiomatics of the formal approach, is noticed to be starting from the base point $\mathrm{e}$ and to be spreading in three axes. The metric of the graph does not change with its spreading's, however, for the image to be observed compactly, each level of construction is scaled a multiple $2 / 3$. So, the Cayley graph obtained in this way could be depicted as following (Fig. 3):

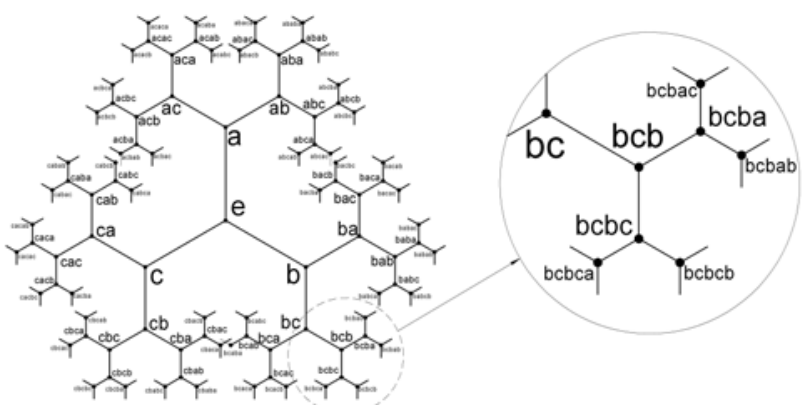

Figure 3 - Cayley's graph of the actions of the skipper in the three-factor model

As it can easily be seen from Fig. 3, the Cayley graph is not observed changing structurally. To some extent at any point the principle of the geometric distribution of edges can be functioning in the same way. This tendency confirms the appropriateness of geometric group theory sampling techniques for further development of this study. In order to analyze this approach, an experiment was carried out using the Transas navigation simulator NTPRO 5000 at the Kherson State Maritime Academy (Ukraine) (Fig. 4).

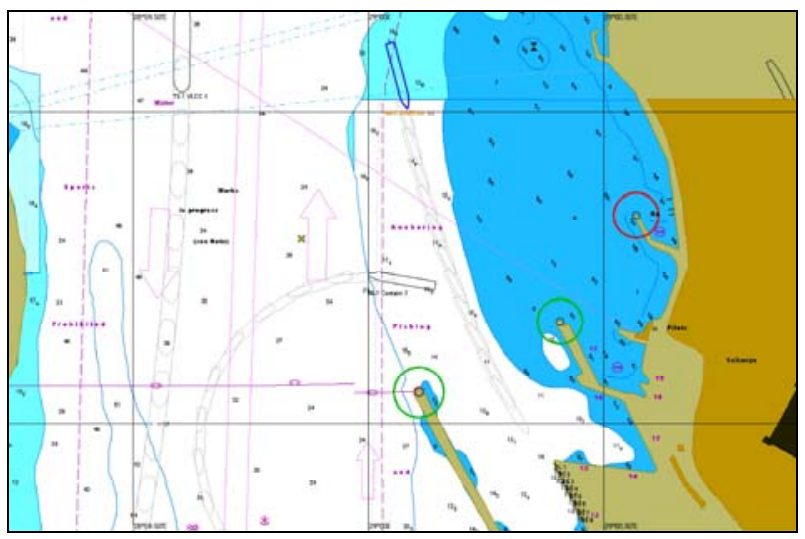

Figure $4-\mathrm{A}$ fragment of the operation on the NTPRO 5000 simulator

Before starting of the experiment students, navigatorsto be, had been pre-screened for upcoming behavior pattern with the following analysis of the actions letting us get identified all preferences regarding directional factors during the mooring operation.

In order to improve the experiment quality and leveling random factors a mooring operation is reported to have been performed in three stages. In each of the stages an extremum was determined by three directional factors towards particular captain. Consequently, three trajectories were obtained mapped onto fragments of the Cayley graph (Fig. 5).
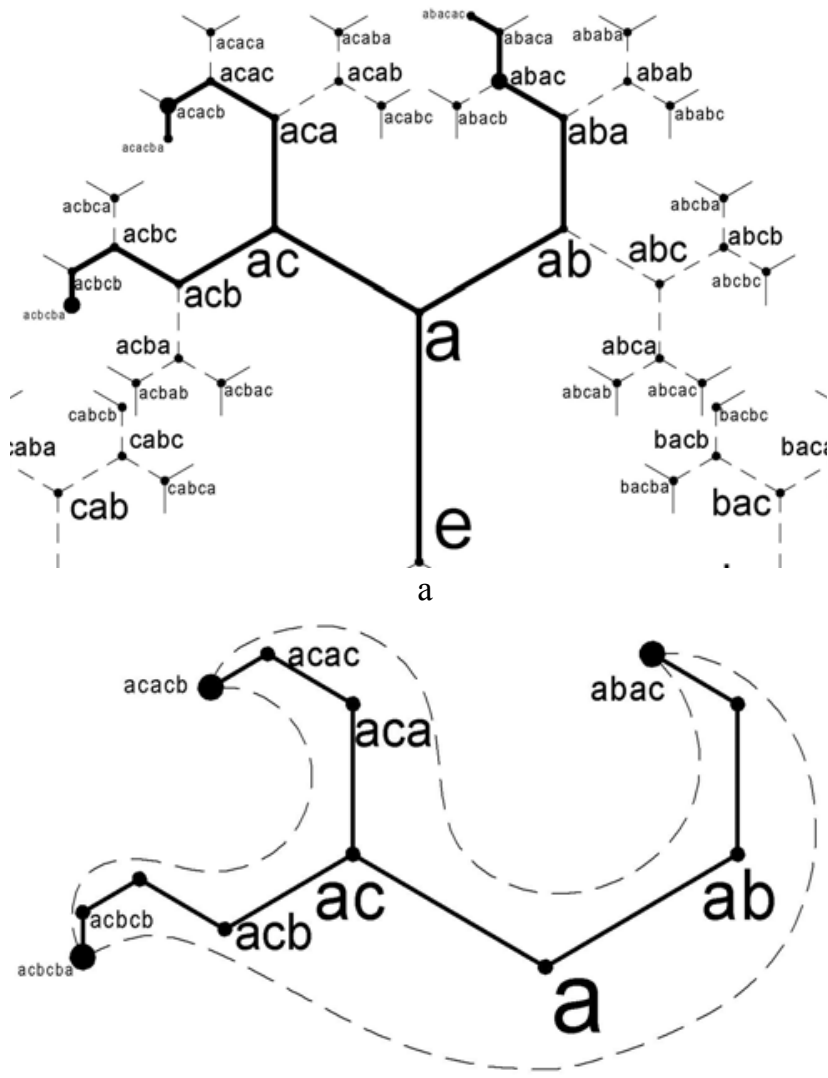

b

Figure 5 - The set of trajectories on the Cayley graph

Fig. 5a shows that all three trajectories begin with a factor-direction $a \in A$, indicating the fact of navigator's having already been formed by the carrying out moment stages action plan. To a certain point, this is real truth due to the fact that the skipper is experienced and has wellestablished behavior algorithms in cases typical to this situation. Having highlighted and connected the extremum points (acbcba, acacb, abac) we get a geometric figure forming a triangle. Attention must be paid to the evidence of functioning each extremum point as a determiner of the length of the trajectories of different sizes (usually from 4 to 6 stages) (Fig. 5 b).

The resulting structure is defined by the central $a-a c$, geodesic segment limiting the outgoing trajectories within a constant $c_{a}$, such that (1):

$$
f\left(x_{g}\right) \exists c_{a}: \forall a \in A, \exists p \in F\left(X_{g}\right): d_{a}(a, p) \leq c_{a} .
$$

(C) Nosov P. S., Popovych I. S., Cherniavskyi V. V., Zinchenko S. M., Prokopchuk Y. A., Makarchuk D. V., 2020 DOI 10.15588/1607-3274-2020-3-15 
Thusly, this structure is not said to be anything more than $c_{a}$-bounded quasi-isometric mapping of the image describing the metric of social expectations of the skipper in a set of typical situations. The introduced constants are not noticed to distort the essence and linear dependence of the three-factor model of the ERO-AEA-EAPI. This data deliver us the possibility of getting generalization the observed properties of the formation of behavior trajectories. The obtained for each trajectory data is fragmented and displayed in Table 1 and according to it, the main extremes turn out to be analyzed and, as a result, it is individual resurfacing of the navigator's social expectations is highly likely to happen (Fig. 6).

Table 1 - The data of the trajectories of the geometric structure

\begin{tabular}{|c|c|c|c|c|c|c|c|}
\hline № & Trajectory & \multicolumn{7}{|c|}{ Trajectory stages } \\
\hline 1 & $a c b c b a$ & $a_{1}$ & $a c_{1}$ & $a c b$ & $a c b c$ & $a c b c b$ & $\boldsymbol{a c b c b a}$ \\
\hline 2 & $a c a c b a$ & $a_{2}$ & $a c_{2}$ & $a c a$ & $a c a c$ & $\boldsymbol{a c a c b}$ & $a c a c b$ \\
\hline 3 & $a b a c a c$ & $a_{3}$ & $a b$ & $a b a$ & $\boldsymbol{a b a c}$ & $a b a c a$ & $a b a c a c$ \\
\hline
\end{tabular}

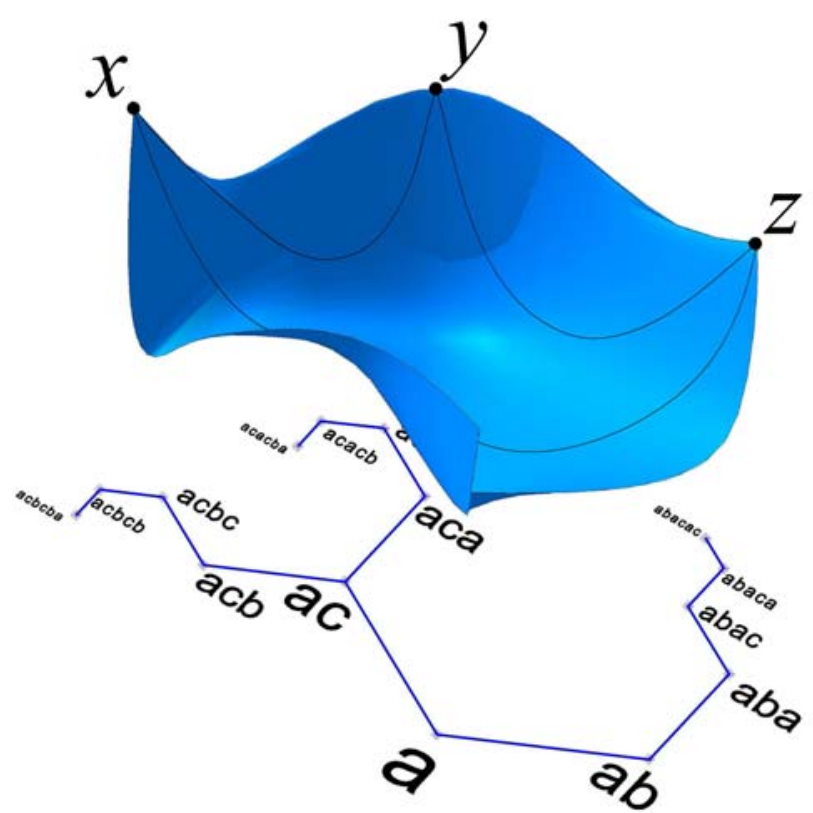

Figure 6 - The curved surface of the social expectations of the individual

Further observation of the specifics of the manifestations of factor directions makes us notice our moving away from the straightness of the Cayley graph due to the scatter of the values determined by its points.

The image of the graph itself can b regarded as an image on a curved surface formed by a matrix of values when forming the trajectories of the real actions of the skipper (Fig. 6). To a certain point, the formed surface is said to be an individual imprint of his social expectations in the situation under consideration (2):

$$
(M, d): \forall x_{g}, y_{g}, z_{g} \in M, \exists \gamma:[0, r] \rightarrow M
$$

The curvature determination of this surface contributes to providing the representation of the impact degree of dominant factors on the situation and to displaying of individual habitual preferences being performed in a typical situation. As a result, possible future behavior pattern of the skipper is highly likely to be predicted. However, taking into account the complexity of this process, an indirect feature is proposed to be used due to the fact of getting real reflection of the deviation from the average indicators of the points. This indirect issue is noticed to be based on the ratio of the area formed by three points of the flat and the actual obtained surface.

The comparative analysis of the area of the flat $S_{1}=4210.04 \mathrm{~mm}^{2}$ and the surface area $S_{2}=9531.18 \mathrm{~mm}^{2}$ is equal to 2.263. Thus, a surge of factors regarding the situation turns out to have double time exceeding average experience which is considered to be treated as true indicator of skipper's mental state.

Therefore, the goal points of social expectations are able to be determined for all three factors-directions of the model of the ERO-AEA-EAPI.

So, the formed space is $\delta$ hyperbolic [23] because (3):

$$
\forall x_{g} y_{g} z_{g} \in M, \forall\left[x_{g}, y_{g}\right],\left[y_{g}, z_{g}\right],\left[x_{g}, z_{g}\right] \rightarrow M \delta
$$

Being proved by the fact that all the geodesic segments in our case are located in the same neighborhood surroundings common trajectory fragments are vividly seen. This issue is confirmed by transition properties (4):

$$
\begin{aligned}
& \exists \delta: \forall \text { geodesic } \Delta \rightarrow \delta \text { narrow } \Rightarrow \exists \delta: \forall \text { geodesic } \Delta \rightarrow \\
& \rightarrow \text { diam }\{\text { center points }-a, b, c\} \leq \delta .
\end{aligned}
$$

It can be observed from formulas (3) - (5) that the this way formed geometric structures have a central space being limited by points $\left(c_{x_{g}}, c_{y_{g}}, c_{z_{g}}\right)$, so called $\delta$ neighborhood. In our case it will have a diameter equal to the edge $a$-ac being completely appropriate for the $c$ limitation condition mentioned above (Fig. 7).

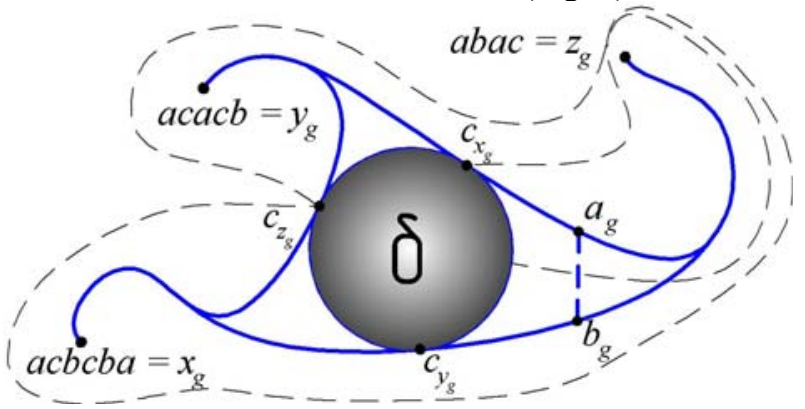

Figure 7 - Is $\delta$-neighborhood surrounding on the geodetic triangle ERO-AEA-EAPI.

Depicted in Fig. 7 a geodesic triangle is quasimetrically embedded being a fragment of the Cayley graph into a hyperbolic space as its $\delta$-fineness, $\left[x_{g}, y_{g}\right] \cup$ $\cup\left[x_{g}, z_{g}\right] \cup\left[y_{g}, z_{g}\right]$ in the metric space $(M, d)$. This situation can easily be determined by the following condi- 
tion: for the vertex $z$ and for any two points $a_{g}$ and $b_{g}$ on its sides $\left[z_{g}, y_{g}\right]$ and $\left[z_{g}, x_{g}\right]$, the next coming item is observed:

$d\left(z_{g}, a_{g}\right)=d\left(z_{g}, b_{g}\right) \leq \frac{1}{2}(d(z, y)+d(z, x)-d(y, z)) \Rightarrow$ $\Rightarrow d\left(a_{g}, b_{g}\right) \leq \delta, \delta>0$.

Consequently, that presented in the scope of this study three-factor model of ERO-AEA-EAPI on this Cayley graph group happens to be mentioned a hyperbolic one basing on the definitions of Gromov-Rips [24, 25]. From the spoken above the conclusion can be made about existing $\delta$-neighborhood surroundings for a finite system of generators where the union of any two sides occur (Fig. 7). As it can be clearly seen, the curvature of the space ERO-AEA-EAPI seems to be situational one and depends on its generators. The result of this as follows: the problem of revealing the pattern of its formation as well as the complication of making classification of the navigator's mental states regarding to extreme points happen to surface.

\section{EXPERIMENTS}

In the light of the foregoing above objective an experiment was carried out using the Transas navigation simulator NTPRO 5000. This experience contributed into succeeding in having the space of the ERO-AEA-EAPI built basing on the results of the navigation tasks of three captains.

During the experiment double having been passing of the location by each of the captains in two similar situations in Bosphorus and Hong Kong was performed. In each case extreme points were identified showing that the obtained data is close enough in meaning, in average comprising about $2-5 \%$. To a certain point, this issue indicates the awareness in performed decision-making process based on many years of experience. Despite the probable static nature of the identified indicators of the model of the ERO-AEA-EAPI, dynamics tended to be found in the form of the displacement of triangular geometric structures towards the geodetic space above the Cayley graph (Fig. 8). For example, being traced in two cases dynamics has various transformations. It must be emphasized that in the first case a significant expansion of the surface area formed by triangles by $65 \%$ is possible to be observed. This fact indicates that the captain No. 2 tends to be shifting the focus of the ERO-AEA-EAPI intentionally at the second stage.

So, for the sake of getting the extremum points figured out an automated system was developed allowing you to visually determine the surface of the triangulation (Fig. 8). This item is sure to indicate the balance of the ERO-AEA-EAPI in the mooring task $Z$.

It must be noted that the long-drawn-out experiment is reported to have been performed in the period of 3.5 years with dozens of trajectories analyzed. Subsequently, the tendency was noticed to follow of having some cases with the dynamics of the displacement of the points of the extrema in time slices.

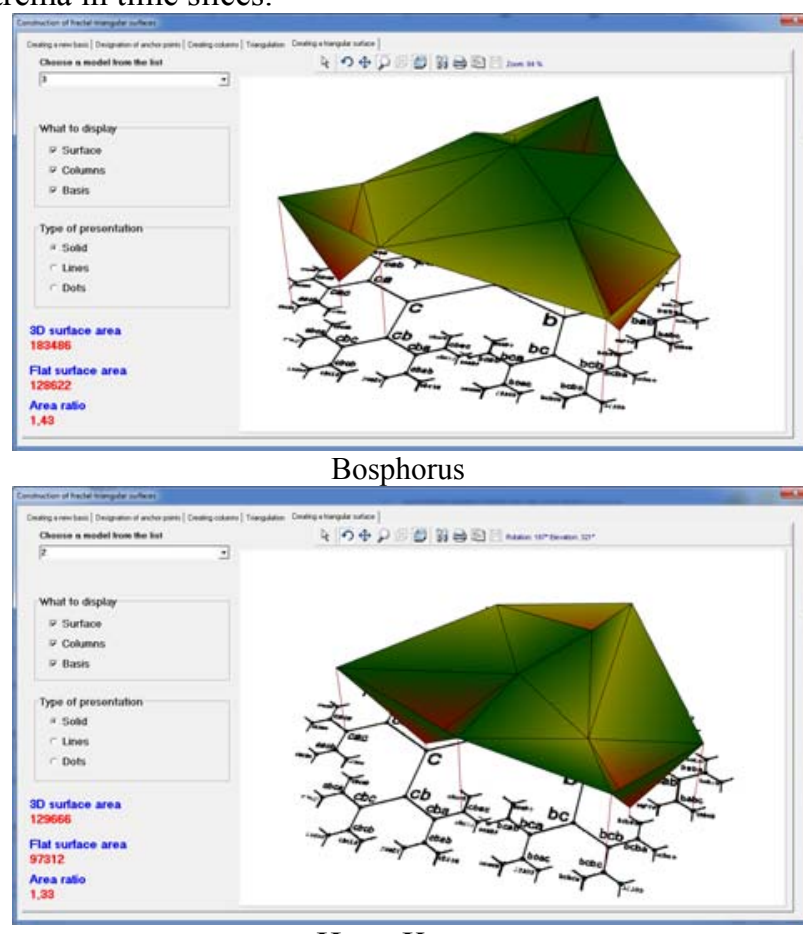

Hong Kong

Figure 8 - Triangulation of the hyperbolic decision surface

The implemented research revealed a bias dependence depending both on the age of the captains and on their psychological states (Fig. 9).
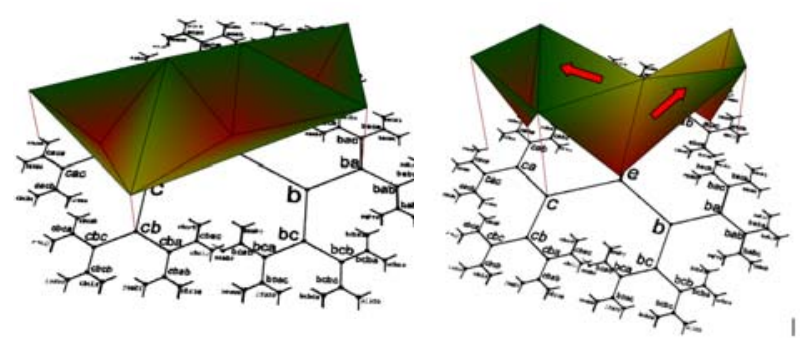

Figure 9 - Dynamics of the transformation of a hyperbolic surface

As a result, a hypothesis is highly likely to be done is that such actions are thought to be habitual characteristics of individuals being still on their way of development and improvement. They are sure to be setting new goals and striving to boost their skills and abilities associated with running the vessel and navigation. The only problem to be mentioned is our being uncertain about this. Appropriately to the aforementioned, there is a need in applying mechanism for the condition determinations for the aim of stimulating the captain to change the strategic trajectory of action.

In this regard, let us consider this situation in the formal theory of creativity framework [26]. According to it, the notion to be used is mooring $Z$, as a decision-making 
task it is to be based on the captain's initial information about the situation $x \in X$, in the form of which the initial action plan is shaped $z \in Z$. The captain's early experience occupies a significant place at this very stage. For instance, with a sufficiently low functional entropy of the captain, the action plan can possibly be determined with a high degree of accuracy $z / Z$, leading to the enormous specification of the action plan $B_{t}(x)$ proposing the only probable- to be carried out-plan $X_{t}^{\wedge}$. Otherwise, the captain tends to be relying indirectly on experience of such type of tasks $Z$, summarizing data $C_{t}(x)$ while having $x \in X_{t}$. This experience seem to form $X_{t} \rightarrow X_{t+1}$ and depict $C_{t}: X_{t} \rightarrow 2 X_{t}$ and $B_{t}: X_{t} \rightarrow 2 X_{t}$

Thus, the expansion of the spectrum of actions by the level of generality $C_{t}(x)$ forms inductors $\{$ Ind $\} Z$, with regard to information domains $D_{j}$, affecting the focus shift of the ERO-AEA-EAPI and determining model $D_{1}\{$ Ind $\} D_{1} \rightarrow D_{2}\{$ Ind $\} D_{2} \rightarrow \ldots \rightarrow D_{j}\{$ Ind $\} D_{j}$.

As a result, the assumption seem to appear that focusing shift is possible to be surfaced when there is either entropy (unconscious action) or (conscious action) if there is a need in having one's social condition improved and, hence, in anticipation itself.

In addition it should be taken into account that detailing and generalization are being involved into complex way functioning: $\forall x \in X_{t} C_{t}(x) \cap B_{t}(x)=x$ is on the problem of mooring $Z$, while new social states knowledge base is being formed and equal to: $x^{\prime} \in C_{t}(x) \Leftrightarrow x \in B_{t}\left(x^{\prime}\right)$. However, these conditions can be reported as being valid only when non-random activity of captain $e$, case is observed such as: $\forall x \in X_{t} e(x) \rightarrow e\left(C_{t}(x)\right)$.

Basing on the fact that all captains due to their qualification base a- priori act consciously rely on their prior experience and skills the mooring problem is to be determined by a predicate $P(x, z)$, such as $\forall x \in X \exists z \in Z P(x, z)$. While having it, the power of the set of probable solutions will be: $\forall x \in X \quad z \in A(x) P(x, z) \quad \& \quad \forall x \in X \quad z \notin A(x) \neg P(x, z)$, where $A: X \rightarrow 2 Z$. In tough close to-emergency situations the captain is obliged to operate with data with a maximum accuracy a criterion which is said to be $\Omega_{t}, H_{t}=\left\{x \mid x \in X_{t}, B_{t}(x) \equiv x\right\}$. This issue enormously reduces and limits the possibility of having options $U_{t}=\bigcap x \in H_{t} C_{t}(x)$, with stimulating the extinction of the extreme points of the ERO-AEA-EAPI.

The manifestation of such situations are causing the captain's mechanical and unemotional actions in the cases when: $\exists x, x^{\prime} \in H_{t}$ that $C_{t}(x) \cap C_{t}\left(x^{\prime}\right)=\varnothing, U_{t}=\varnothing$ and $\forall x \in X_{t}^{\wedge} \exists ! z x P(x, z x)$, when such tough situation is highly likely to happen: $\forall x^{\prime} \in C_{t}(x) \cap X_{t}^{\wedge} P\left(x^{\prime}, z x\right)$

Therefore, for mooring operation to succeed a trajectory, $\left\{x_{n}\right\} x \equiv\left\{x=x_{0}<x_{1}<\ldots<x_{n}\right\} \subset X_{t}^{\wedge}$ is to be provided escaping from getting the entry to the close-toemergency situation described by the set of $X_{t}^{*}=\left\{x^{*} \mid x^{*} \in X_{t} \exists ! z \in Z P\left(x^{*}, z\right)\right\}$ or emergency one like $X_{t}^{+}=\left\{x \mid x \in X_{t} P(x, u)\right\}=X_{t} \backslash X_{t}^{\wedge}$. It is worth adding that such situation may condition the time frame to be determined forming the pre-emergency state of the mooring operation $X_{t}=X_{t}^{\wedge} \backslash X_{t}^{*}$. However, the complexity of having it done is the fact in each captains' having individual temporary structures according to their background nature displayed in the trajectories of behavior. It makes ground to welcome necessity of determination an individually-oriented model of the captain taking into account the time phases of effectiveness of safe providing model of navigation.

On account of all spoken above, let us turn to the formal concept defining individual temporary "codes" of captains within the framework of tackling such indicated problem mooring operation of the vessel: $\forall x \in X_{t}^{*} \exists ! z \in Z P(x, z)$.

Premising, all three time phases of its solution are considered as being $\quad X_{t}^{\wedge}=\bigcup z \in Z\left(X_{t}^{\wedge}\right) z$; $X_{t}^{*}=\bigcup z \in Z\left(X_{t}^{*}\right) z ; \quad \forall z \in Z\left(X_{t}^{\wedge}\right) z \rightarrow e\left(X_{t}^{*}\right) z$, with the transition to is undiscrete they staged by means of adding certain conditions, $V=(x \rightarrow z x)$ in individual way for each captain. Then, each piece of information $x \in X_{t}^{\wedge}$, affecting the decision-making strategy needs to be tracked.

It is worth mentioning that before the mooring, at a certain point in time, the set of rules is primarily formed $\Omega_{t}=\left\{\alpha=\langle x \alpha, z \alpha\rangle \mid x \alpha \in H_{t}\right\}_{t}$ and is unable to provoke spontaneous phase transitions. However, the surfacing the new ones, being quite unpredictable $\left(X_{t}^{*}\right) \alpha$, can cause leveling the preliminary plan and form an initial set of decision-making rules opposite to the first one $\left\{S^{*}\right\} \alpha=\left\{x^{*} \rightarrow z \alpha \mid x^{*} \in\left(X_{t}^{*}\right) \alpha\right\}$.

Experimental data provide clear evidence that the captain, due to lack of time, as a rule, is not used to change the initial plan not observing any threat to the vessel safety. At the same time, if there is time for the strategy to be changed $W_{t}, Z$ is a cause for the coming out experience of a thin section $X_{t+1}^{*}$, anticipation. It is no doubt that it is able to produce both a positive effect in the captain's knowledge base and a negative one reducing the safety of navigation up to having catastrophic consequences. Con- 
sequently, when the captain has enough time to form a chain of events of the form it looks like:

$$
\begin{aligned}
& \Omega_{t}=\{V\}_{0} \rightarrow W_{t, Z}\left(\{V\}_{0}\right) \rightarrow W_{t, Z}{ }^{\circ n}\left(\{V\}_{0}\right) \rightarrow \ldots \\
& \rightarrow W_{t, Z}{ }^{\circ n}\left(\{V\}_{0}\right)=\left\{S^{*}\right\}_{t}, \text { Full, }\{V\}_{t}, \text { Full }=\bigcup k= \\
& =0,1,2, \ldots, n W_{t}, Z^{\circ k}\left(\{V\}_{0}\right), E Z \geq 0, \text { it happens } \mathrm{H}_{t} \rightarrow \\
& \rightarrow W_{t, Z}\left(H_{t}\right) \rightarrow W_{t, Z}{ }^{\circ n}\left(H_{t}\right)=X_{t}^{*}, E Z \geq 0 .
\end{aligned}
$$

\section{RESULTS}

In this way, we are to emphasize that the conditions are nominally highlighted. They are said to be affecting the captain's ability to reach a decision possible to introduce changes into his model of knowledge base and welcome new ideas regarding the current task $W_{t}, Z^{\circ k}\left(\{V\}_{0}\right)$. During the experiments two vectors of the captain's transition to a qualitatively new level of perception of the navigation situation were noticed to be identified: the first is a change of strategy during the implementation of the initial navigation plan $(17 \%)$; the second one concerns the formation of a new preliminary plan (36\%) after $\mathrm{n}$ homogeneous ones $X_{t-m}$. The remaining $47 \%$ percent of cases reflect not having changed of the strategy approach of the captains while performing the mooring operation even in spite of getting new information signals come out. Thus, the conclusion highly likely to be done is that captains capable of transition $X_{t+1}^{*}$, may successfully manage with differentiation between a situation with a familiar dataset and a situation with a new one. Simultaneously, the transition $X_{t+1}^{*}$ is possible to be done through a spiral cycle from detailing $a_{t}$ to generalizing $b_{t}$ and back to detailing $a_{t+1}$.

So, generally this algorithm can beneficially be represented in the framework of the Shukhart - Deming cycle [28] completely confirming the research hypothesis
(Fig. 9, 10).The diagram catches that the cycle $a_{t} \rightarrow b_{t} \rightarrow a_{t+1}$ is a key issue in having shift process of the extreme points ERO-AEA-EAPI. Therefore, the mechanism for transition formation in the cycle must be determined by means of selecting individual tests for each captain.

It is worth noticing that provided data granted us the opportunity to determine the factors of permitted -to bedone activity of the captains which is reported to become the basis of the tests $\tau$ when performing a wide range of navigation tasks $-\tau / T$.

The formal presentation of the mechanism is considered to be defined as a digraph $G(\tau)=\left\{T \rightarrow e T^{\prime}\right\}_{\tau}$. This case must oblige us to draw special attention to the identification of attention areas focused on primary details:

$$
\forall \tau / T\left\{e_{t+1}(\tau / T)\right\}=E \tau / T, t(Z(t),\{G(a)\}, E)
$$

The fact of the coherence $C(\tau / T)$ of the navigation operations during activation of $\tau$ and sufficient energy and time can be treated in such way as: if $e(\tau / T)=1 \Rightarrow e(C(\tau / T))=1 \& e(T \backslash \tau)=0$, while having it the shift is $\forall T \rightarrow T^{\prime}\left\{e_{t+1}\left(T \rightarrow T^{\prime}\right)\right\}=E T \rightarrow T^{\prime}, t(Z(t),\{G(a)\}, E)$. So, basing on the principles of quantitative-qualitative transition we are to observe $G v(\tau) \mid \Rightarrow \Xi G \Xi(\tau)$. The assumption that $G_{l+1}(\tau)=\theta G, \tau\left(G_{l}(\tau)\right)$, where $l=1,2, .$. , $m$, and $\theta G, \tau$ is a set of elementary operations of digraph development is proposed to be paid attention.

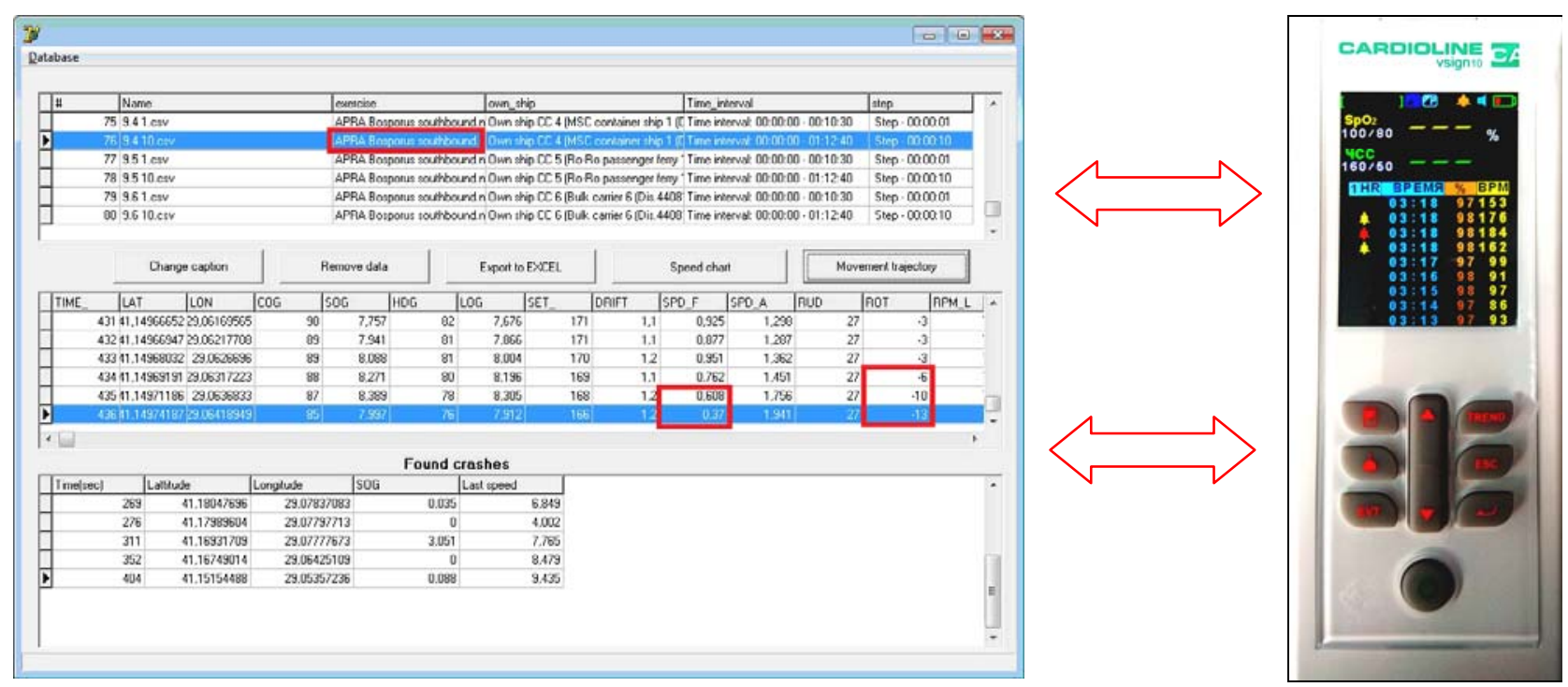

Figure 9 - NTPRO 5000 Simulator Database Analysis 


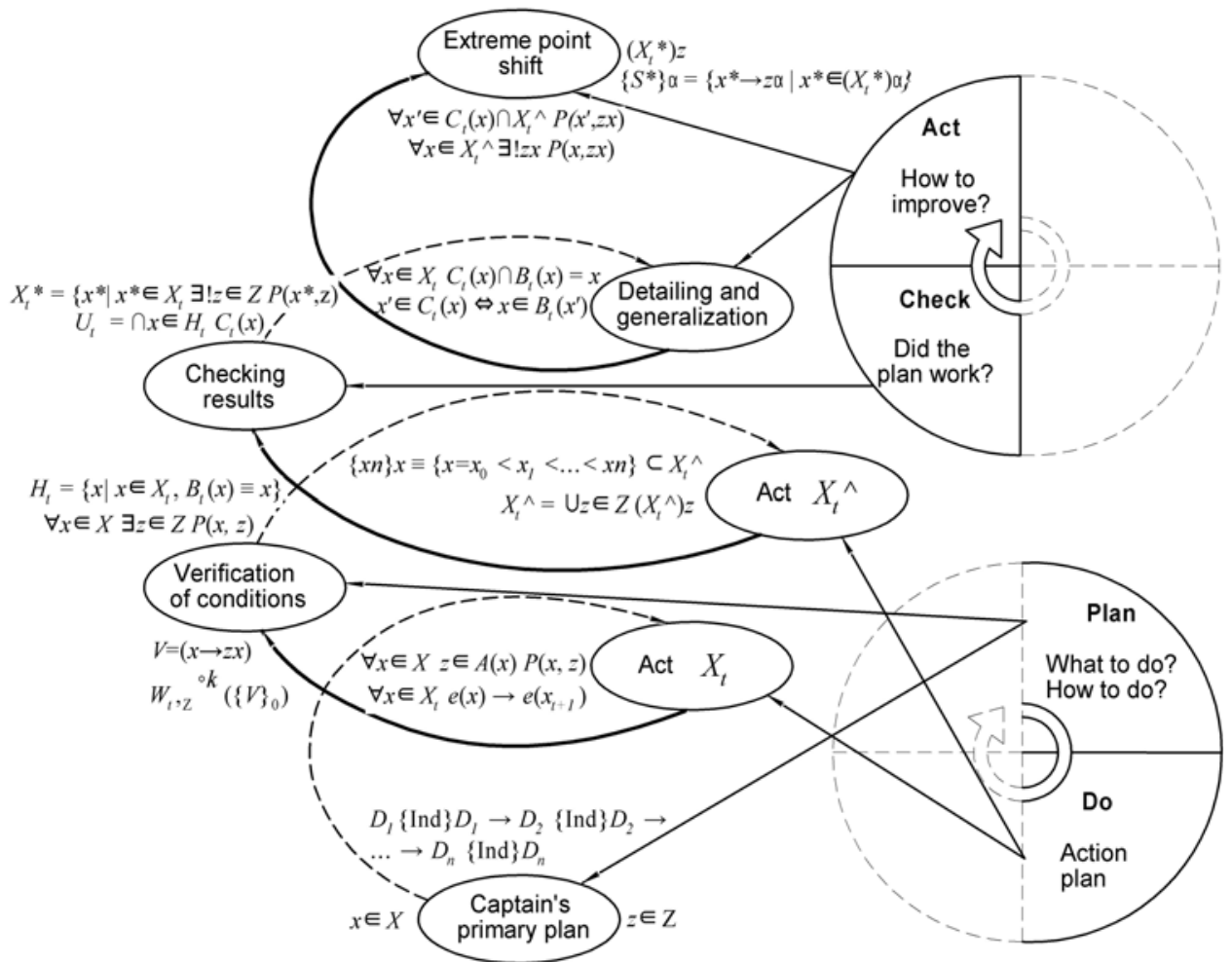

Figure 10 - A model of the dynamics of operators' anticipation centers

Then, the test performance is certain to be depicted by the dependence as follows:

$G v(\tau) \mid \Rightarrow\{Z$ Task $\} G$, if $e(\tau / T)=1 \Rightarrow e(T$ Task $)=1$,

for $\{A g\}|\Rightarrow G(\tau) \&\{G(a)\}| \Rightarrow G(\tau)$.

Three-coordinate metric depicts as follows:

$-x$ is the set of previous navigation tasks $\tau / T$;

$-y$ is the ratio of the diameter of the inscribed triangle with the diameter $\delta$;

$-z$ is the coefficient of deviation of the triangular surface from the flat on the Cayley graph.

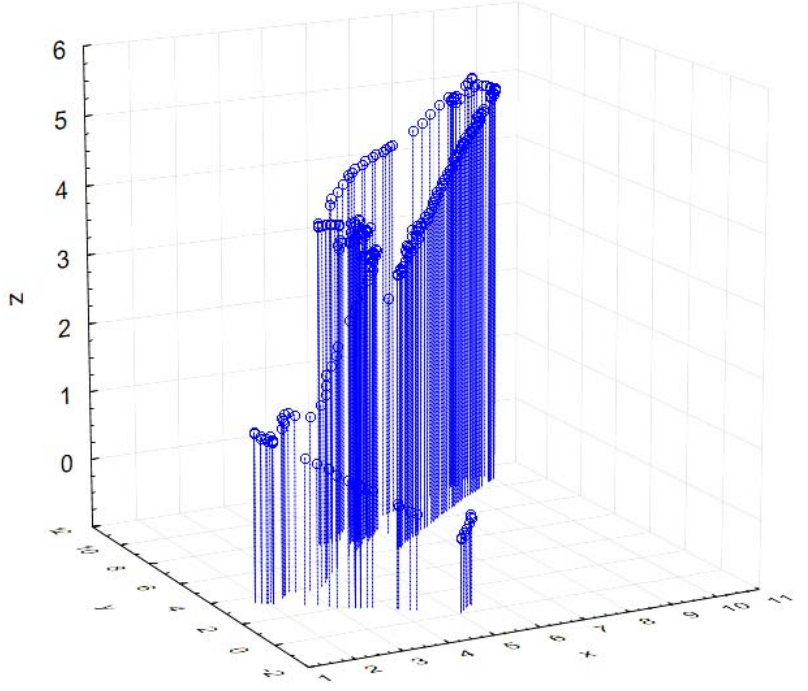

Figure $11-x y z$ scatter chart
The scatter diagram (Fig. 11) shows the relationships between the points, with none -speaking of random outliers, having the form of a fragmented trajectory. It confirms the transition hypothesis in accordance with conditions and external factors. The scatter of states mainly witnesses for having all evolutional increases of the indicators in $x y z$ up.

Let us construct a regression using automated neural nets as it seems to be named as the most effective method for processing the data of the presented dimensions [29]. Suppose, the settings of the samples might be admitted as follows: training is $70 \%$; control and test are both equal to $15 \%$ with getting the number of subsamples equal to 12 . Let us take a multi-layer perceptron being a type of neural net, 20 nets for training and 5 ones for output as the best issues to be chosen from.

In addition, for comparison purposes we might be using a custom neural network. To do this, the hyperbolic function of network activation is to be chosen singling out 5 networks for training and the number of hidden neurons. Further, for the perceptron the second-order accuracy algorithm BFGS and the number of items is $3000 \mathrm{i}$ reported to be taken (Fig. 12, Fig. 13).

\begin{tabular}{|c|c|c|c|c|c|c|}
\hline \multicolumn{7}{|c|}{ Active neural networks } \\
\hline Net. ID & Net. name & Training perf. & Test perf. & Validation perf. & Algorithm & Error funct \\
\hline 2 & MLP 3-6-1 & 0,866019 & 0,963812 & 0,952913 & BFGS 137 & sos \\
\hline 3 & MIP $3-1 n-1$ & ก.944חก1 & ก930ก48 & ก.964935 & REFSS 255 & sns \\
\hline 4 & MLP 3-9-1 & 0,899128 & 0,973911 & 0,976353 & BFGS 283 & SOS \\
\hline i & & III & & 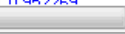 & & 1 \\
\hline 臨品 & SelectiDesel & tactive networks & & & elete networks & \\
\hline
\end{tabular}

Figure 12 - Best MLP Network 3-9-1 


\begin{tabular}{|c|c|c|c|c|c|c|c|}
\hline \multicolumn{8}{|c|}{ Active neural networks } \\
\hline Net. ID & Net. name & Training perf. & Test perf. & Validation perf. & Algorithm & Error funct & \\
\hline 6 & $M I P=2-4-1$ & 0512810 & 0280650 & 0254278 & BEGS 5A & sos & \multirow[t]{2}{*}{$\equiv$} \\
\hline 7 & MLP 3-4-1 & 0,895043 & 0,971929 & 0,974676 & BFGS $29 .$. & SOS & \\
\hline${ }^{\circ}$ & MLLF $S^{-4}-1$ & 0,8055000 & 0,965011 & 0,982401 & Bras 159 & sos & \multirow[t]{2}{*}{ - } \\
\hline : & M.AI P $2 . A .1$ & ПFEFGQR & ก A730325 & ก57231? & & sna, & \\
\hline 譼 & Selecthes & t active networl & s & & elete network & & \\
\hline
\end{tabular}

Figure 13 - Best MLP Network 3-4-1

To obtain the most effective models a neural network basing on the multiple subsampling method is intended to be constructed (Fig. 14). For meeting these requirements the radial basis function and the number of hidden neurons equal to 30 are offered to be taken.

\begin{tabular}{|c|c|c|c|c|c|c|c|}
\hline \multicolumn{8}{|c|}{ Active neural networks } \\
\hline Net. ID & Net. name & Training perf. & Test perf. & Validation perf. & Algorithm & Error funct & 1. \\
\hline 11 & RBF 3-30-1 & $-0,129662$ & $-0,100111$ & $-0,036909$ & RBFT & sos & \\
\hline 12 & RBF 3-30-1 & $.0,061876$ & $-0,049986$ & $.0,091447$ & RBFT & $\operatorname{sos}$ & \\
\hline 13 & RBF $3-30-1$ & $.0,089920$ & $-0,100461$ & $-0,136163$ & RBFT & SOS & \\
\hline \multicolumn{8}{|c|}{ 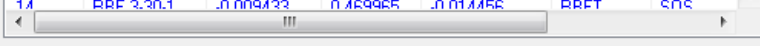 } \\
\hline 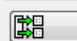 & Selecthose & active networ & $s$ & & elete netwo & & \\
\hline
\end{tabular}

Figure 14 - Using the radial basis function

As can clearly be seen the radial basis function delivers disproportionately low rates not granting its use for the sample. The total learning outcomes of neural networks are presented on Fig. 15.

\begin{tabular}{|r|r|r|r|r|r|r|r|}
\hline \multicolumn{8}{|c|}{ Summary of active networks (Лuct1 in ! crat) } \\
\hline Index & Net. name & Training perf. & Test perf. & $\begin{array}{c}\text { Validation } \\
\text { perf. }\end{array}$ & Training error & Test error & $\begin{array}{c}\text { Validation } \\
\text { error }\end{array}$ \\
\hline 23 & MLP 3-4-1 & 0,885490 & 0,978961 & 0,601386 & 0,000012 & 0,0000066 & 0,0040663 \\
24 & MLP 3-4-1 & 0,595815 & 0,366749 & 0,551690 & 0,000033 & 0,000094 & 0,000102 \\
25 & MLP 3-4-1 & 0,647822 & 0,655474 & 0,366311 & 0,000045 & 0,000062 & 0,000045 \\
\hline 26 & MLP 3-4-1 & 0,422836 & 0,595017 & 0,283890 & 0,000050 & 0,000018 & 0,000164 \\
\hline 27 & MLP 3-4-1 & 0,935426 & 0,901746 & 0,906628 & 0,000009 & 0,000019 & 0,000015 \\
\hline 28 & MLP 3-4-1 & 0,832792 & 0,897238 & 0,748960 & 0,000019 & 0,000050 & 0,000010 \\
\hline 29 & MLP 3-4-1 & $-0,034971$ & 0,174446 & 0,389461 & 0,000052 & 0,000071 & 0,000170 \\
\hline 30 & MLP 3-4-1 & 0,397231 & 0,427485 & 0,019626 & 0,000075 & 0,000024 & 0,000058 \\
\hline 31 & MLP 3-4-1 & 0,392804 & 0,685555 & 0,017583 & 0,000071 & 0,000012 & 0,000077 \\
\hline 32 & MLP 3-4-1 & 0,405597 & 0,555839 & 0,497110 & 0,000077 & 0,000022 & 0,000017 \\
\hline 33 & MLP 3-4-1 & 0,388823 & 0,645078 & 0,351217 & 0,000068 & 0,000017 & 0,000071 \\
34 & MLP 3-4-1 & 0,862818 & 0,943959 & 0,449031 & 0,000019 & 0,000012 & 0,000028 \\
\hline
\end{tabular}

Figure 15 - Model Performance Comparison

Suppose, let us conduct a graphical analysis of the adequacy of simulated neural networks by the help of a scatter diagram (Fig. 16), and response variables in the form of a three-dimensional diagram (Fig. 17).

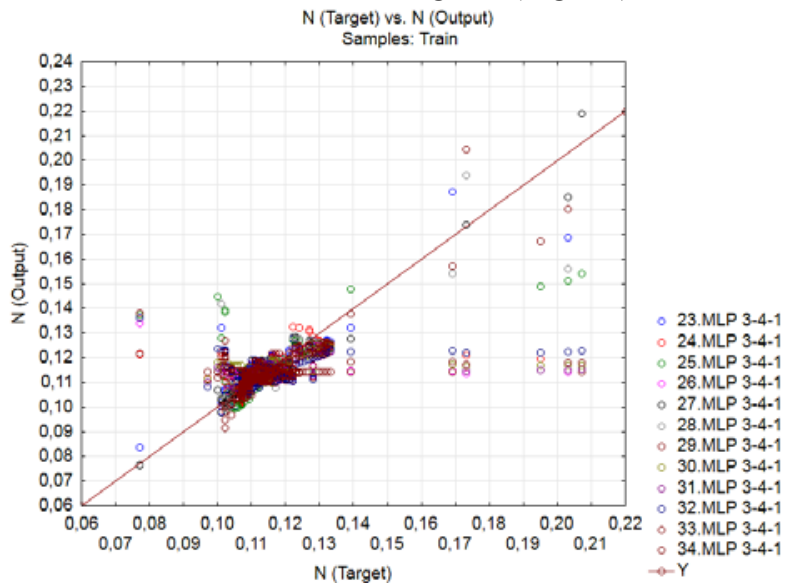

Figure 16 - Scatter Diagram Analysis of the adequacy of simulated neural networks using $x$ (Input), y (Input), N (Output) [34.MLP 3-4-1]

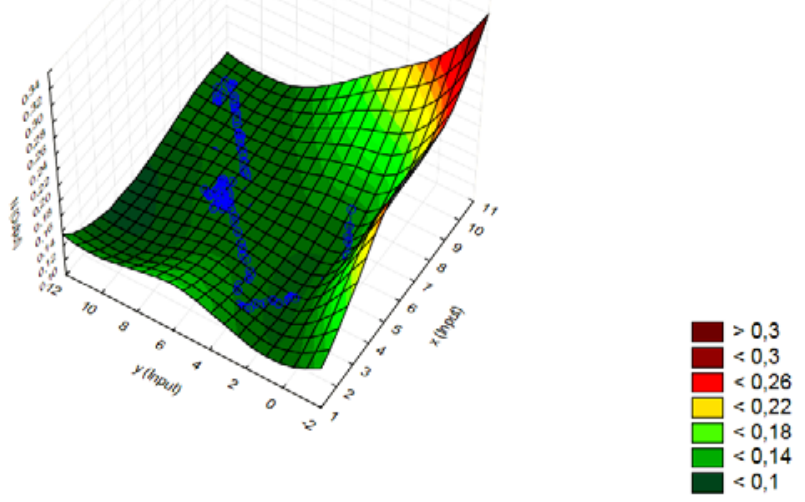

Figure 17 - Three-dimensional diagram of response variables

According to the scatter diagram the accumulation of points is being depicted as a normal one and the number of outliers is being shown a random one. In addition, a three-dimensional reliability diagram is sure to display well enough the dependence of variables and surface showing rather high sufficiency.

In its turn, analysis of the sensitivity of the variables showed that the variable $z$,"the coefficient of deviation of the triangular surface from the flat on the Cayley graph", is considered to be the most significant. This point testifies in favor of the hypothesis of the study (Fig. 18).

\begin{tabular}{|l|r|r|r|}
\hline \multirow{2}{*}{ Networks } & \multicolumn{3}{|c|}{$\begin{array}{l}\text { Sensitivity analysis (Лист1 in ! } \\
\text { Samples: Train }\end{array}$} \\
\cline { 2 - 4 } & \multicolumn{1}{|c|}{$z$} & \multicolumn{1}{|c|}{$y$} & \multicolumn{1}{c|}{$x$} \\
\hline 23. MLP 3-4-1 & 20956,2 & 47,3 & 27931,83 \\
\hline 24. MLP 3-4-1 & 15,3 & 19,1 & 2,18 \\
\hline 25. MLP 3-4-1 & 5605,6 & 51,8 & 5,84 \\
\hline 26. MLP 3-4-1 & 7,2 & 5,9 & 1,14 \\
\hline 27. MLP 3-4-1 & 294388,4 & 332621,3 & 4,13 \\
\hline 28.MLP 3-4-1 & 66736,1 & 51135,9 & 492,55 \\
\hline 29. MLP 3-4-1 & 1,0 & 1,0 & 1,00 \\
\hline 30. MLP 3-4-1 & 7,7 & 6,3 & 1,02 \\
\hline 31. MLP 3-4-1 & 8,2 & 7,2 & 1,04 \\
\hline 32.MLP 3-4-1 & 11,9 & 13,0 & 1,19 \\
\hline 33. MLP 3-4-1 & 9,3 & 7,1 & 1,23 \\
\hline 34. MLP 3-4-1 & 1467,7 & 258,6 & 5,29 \\
\hline Average & 32434,6 & 32014,5 & 2370,70 \\
\hline
\end{tabular}

The analysis of the model for predicting conditions turned out to show rather high values. Thus, it becomes possible to create environment likely to escape from having negative manifestations of the human factor of the operator (Fig. 19).

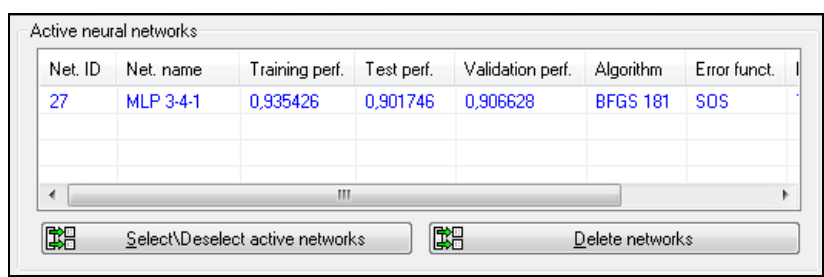

Figure 19 - Prediction of model No. 27 states

(C) Nosov P. S., Popovych I. S., Cherniavskyi V. V., Zinchenko S. M., Prokopchuk Y. A., Makarchuk D. V., 2020

DOI 10.15588/1607-3274-2020-3-15 
Suppose, let us find out the quality of model 27. So, the average value, with the relative error on the test set as being $3.5 \%$ ( 0.0350806479$)$, indicates the high quality of the constructed neural network models (Fig. 20).

\begin{tabular}{|l|l|}
\hline $\begin{array}{l}\text { Case } \\
\text { name }\end{array}$ & $\begin{array}{l}\text { Predictions spreadsheet for N (Лист1 in ! стат) } \\
\text { Network: 27.MLP 3-4-1 } \\
\text { Samples: Test }\end{array}$ \\
\cline { 2 - 2 } & $\begin{array}{c}1 \\
\text { Mape }\end{array}$ \\
\hline MEAN case 1-50 & 0,0350806479 \\
\hline &
\end{tabular}

Figure 20 - Quality analysis of model No. 27

\section{CONCLUSIONS}

The conclusion reached is that formal approaches, models and algorithms have succeeded providing a positive result in identification of anticipation of operators in maritime transport.

The results of the experiment using NTPRO 5000, as well as the developed software, have created the environment favorable to identify either the fact of the manifestation of operator anticipation on the decision path nor to track its dynamics over a long period in addition.

Automated identification rests on the hypothesis that the manifestation of anticipation in operators are highly likely to have been implementing during the time of performing complex maneuvers when navigating the marine transport. Reaching the research outcome was possible to be carried out by means of the use of formal approaches and automation within the framework of decision support systems. To meet these results the metric space $Y_{g}$ with a metric $d_{y_{g}}$ were constructed to display the manifestations of anticipation of the operator.

In order to form the trajectory of decision-making by the maritime transport operator a three-factor model ERO-AEA-EAPI was proposed to be done on the surface of Cayley graph $X_{g}$ with a metric $d_{x_{g}}$. The synchronization of the data of the NTPRO 5000 navigation simulator enable the identification of the extrema on the Cayley graph of the quasi-isometric surface. The mentioned above identified surface distortion in the form of $\delta$ neighborhood surrounding let us find out the operator's anticipation centers.

It must be heighted that the experiment using the Transas navigation simulator NTPRO 5000 have verified the research hypothesis. These issues were profitably coped with thanks to the developed automated module for constructing a triangular space. Besides, identification of the centers, magnitude and dynamics of anticipation of operators were succeeded to be achieved.

Singled out indicators of anticipation $x^{\prime}$ as well as the influence of new data on the psycho-physiological parameters of the operator are reported to be beneficial contributors to the development of a model of the dynamics of operators' anticipation centers in the form of a spiral Shukhart-Deming cycle. The further tendency in studying was stated as receiving an artificial neural network for the sake of having predictions about the likely negative mani(C) Nosov P. S., Popovych I. S., Cherniavskyi V. V., Zinchenko S. M., Prokopchuk Y. A., Makarchuk D. V., 2020 DOI 10.15588/1607-3274-2020-3-15 festations of anticipation in discrete form by constructing multiple regression.

Thus, this study allowed us to step forward in problem solving of identification and predicting the anticipation of operators in maritime transport by introducing DSS with an aim of creating and enhancing safety environment in maritime transport.

\section{ACKNOWLEDGEMENTS}

The work is carried out within the framework of "Development of software for important the quality of functioning systems for dynamic position sea vessels" (state registration number 0119U100948), of navigation and ECDIS departments of Kherson State Maritime Academy Navigation Faculty (scientific adviser: Ph.D. Associate Professor, Deputy Rector for scientific and pedagogical work, Kherson State Maritime Academy, Ukraine, Ben A. P.).

\section{REFERENCES}

1. Harati-Mokhtari A., Wall A., Brooks P. at al. Automatic Identification System (AIS): Data Reliability and Human Error Implications, Journal of Navigation, 2007, Vol. 3, Issue 60, pp. 373-389. DOI:10.1017/S0373463307004298.

2. Be in Command by Knowing These ECDIS Safety Settings. Written by Capt Rajeev Jassal (on August 20), 2016 [Electronic resource]. Access mode: https://www.myseatime.com/blog/detail/be-in-command-byknowing-these-ecdis-safety-settings.

3. Yurzhenko A. An E-course based on the LMS Moodle to teach "Maritime English for Professional purpose", Information Technologies and Learning Tools, 2019, Issue 71, P. 92. DOI: 10.33407/itlt.v71i3.2512.

4. Zinchenko S. M., Ben A. P., Nosov P. S. et al. Improving Accuracy and Reliability in Automatic Ship Motion Control Systems, Radio Electronics, Computer Science, Control, 2020, Vol. 2, pp. 183-195.

5. Nosov P. S., Zinchenko S. M., Popovych I. S. et al. Diagnostic system of perception of navigation danger when implementation complicated maneuvers, Radio Electronics, Computer Science, Control, 2020, Vol. 1, pp. 146-161. DOI: 10.15588/1607-3274-2020-1-15.

6. Nosov P., Palamarchuk I., Zinchenko S. at al.]Development of means for experimental identification of navigator attention in ergatic systems of maritime transport, Bulletin of University of Karaganda. Technical Physics, 2020, Vol. 1, Issue 97, pp. 58-69. DOI: 10.31489/2020 Ph1/58-69.

7. Geometric group theory. Malyutin, A. (2020) [Electronic resource]. Access mode: https://www.lektorium.tv/node/32971

8. Kononenko O., Kononenko A., Stynska V. et al. Research of the factor structure of the model of world view settings at a young age, Revista Inclusiones, 2020, Vol. 7, pp. 98-116.

9. Powell E., Klinck J., Munroe D. et al. The value of captains' behavioral choices in the success of the surfclam (spisula solidissima) fishery on the U.S. Mid-Atlantic Coast: a Model Evaluation, Journal of Northwest Atlantic Fishery Science, 2020, Vol. 47, pp. 1-27. DOI: 10.2960/J.v47.m701.

10. Pinheiro L., Fortes C., Santos J. Risk Analysis and Management of Moored Ships in Ports, 37th International Conference on Ocean, Offshore and Arctic Engineering, Madrid, 17-22 June 2018: proceedings. ASME, 2018. V003T02A057. DOI:10.1115/OMAE2018-78396 
11. Chen L., Rong-chang C. Current problems and risk analysis on high pollution risk operation of ship, 5th International Conference on Transportation Information and Safety (ICTIS). Liverpool, 2019, pp. 136-140. DOI:10.1109/ICTIS.2019.8883804.

12. Gluver H., Olsen D. Current practice in risk analysis of ship collisions to bridges, Ship Collision Analysis: book. Copenhagen, 2018, pp. 85-96 DOI:10.1201/9780203739778-9.

13. Lee H-W., Rhyu H-I. Antiaging strategy considering physiological characteristics, Journal of Exercise Rehabilitation. 2019, Vol. 15, pp. 346-350. DOI:10.12965/jer.1938214.107.

14. Yu H., Guo D. Study on Physiological Characteristics of Emotion, Fifth International Conference on Instrumentation and Measurement, Computer, Communication and Control (IMCCC). Qinhuangdao, 2015, pp. 1286-1289, DOI:10.1109/IMCCC.2015.276.

15. Kurdel P., Lazar T., Labun J. Computing skills in aviation ergatic systems, 12th International Symposium on Applied Machine Intelligence and Informatics (SAMI): IEEE. Herl'any, 2014, pp. 375-379. DOI: 10.1109/SAMI.2014.6822443.

16. Millán P., Inglada-Pérez L., Casares P. et al. Modelización del transporte marítimo de contenedores, Estudios de Economía Aplicada, 2019, Vol. 36, pp. 675. DOI: 10.25115/eea.v36i3.2548.

17. Ertogan M., Tayyar G., Wilson P. et al. Marine measurement and real-time control systems with case studies, Ocean Engineering, 2018, Vol. 159, P. 457-469. DOI: 10.1016/j.oceaneng.2018.02.001.

18. Wang X., Fu T., Zhang Y. et al. Information Interface of Artificial Intelligence Medical Device Information, Big Data Analytics for Cyber-Physical System in Smart City, 2020, Vol. 1117, pp. 1293-1303. DOI: 10.1007/978-981-152568-1 180.

19. Zinchenko S. M., Nosov P. S., Mateychuk V. M. et al Automatic collision avoidance with multiple targets, including maneuvering ones, Radio Electronics, Computer Science, Control, 2019, Vol. 4, pp. 211-221. DOI: 10.15588/1607-3274-2019-4-20.
20. Zinchenko S., Nosov P., Mateichuk V. et al. Automatic collision avoidance system with many targets, including maneuvering ones, Bulletin of University of Karaganda. Technical Physics, 2019, Vol. 4, pp. 69-79. DOI: 10.31489/2019Ph4/69-79.

21. Patané I., Cardinali L., Salemme R. et al.]Action Planning Modulates Peripersonal Space, Journal of Cognitive Neuroscience, 2018, Vol. 31, pp. 1-14. DOI: 10.1162/jocn_a_01349.

22. Vişan M., Ionita A., Filip F. Data Analysis in Setting Action Plans of Telecom Operators, Challenges and Applications. Studies in Computational Intelligence. Springer, 2020, Vol. 869. DOI: 10.1007/978-3-030-39250-5 6.

23. Malyutin A. Pretrees and Arborescent Convexities, Journal of Mathematical Sciences, 2016, Vol. 212, pp. 566-576. DOI: 10.1007/s10958-016-2689-1.

24. Gromov M., Gersten S. M. ed. Hyperbolic groups. Essays in group theory, MSRI Publ. 8. Springer-Verlag, 1987, pp. 75263.

25. Rips E., Sela Z. Structure and rigidity in hyperbolic groups, Geom. Funct. Anal., 1994, No. 3, pp. 337-371.

26. Prokopchuk Y.A. Sketch of the Formal Theory of Creativity. Dnepr, PSACEA Press, 2017, 452 p.

27. Lerche J., Neve H., Wandahl S. et al. Combining Takt and Deming Cycles at Operator Level - Practical Study, The 10th International Conference on Engineering, Project, and Production Management, January, 2020, pp. 623-632.

28. Lymariev I. O., Subbotin S. A., Oliinyk A. A. et al. Method of large-scale signals transformation for diagnosis in neural network models, Radio Electronics, Computer Science, Control, 2018, Vol. 4, pp. 121-134. DOI: 10.15588/16073274-2018-4-11

29. Subbotin S. A. Methods of synthesis of models of quantitative dependencies in the basis of trees of regression, realizing cluster - regression approximation by precedents, Radio Electronics, Computer Science, Control, 2019, Vol. 3, pp. 76-85. DOI: 10.15588/1607-3274-2019-3-9

Received 26.06.2020 Accepted 22.08.2020.

\section{УДК 004.942: 316.454.54}

\section{АВТОМАТИЗОВАНА ІДЕНТИФІКАЦІЯ АНТИЦИПАЦІЇ ОПЕРАТОРА НА МОРСЬКОМУ ТРАНСПОРТІ}

Носов П. С. - канд. техн. наук, доцент кафедри судноводіння та електронних навігаційних систем Херсонської державної морської академії, Україна.

Попович І. С. - д-р наук, професор кафедри загальної та соціальної психології Херсонського державного університету, Україна.

Чернявський В. В. - д-р наук, професор, ректор Херсонської державної морської академії, Україна.

Зінченко С. М. - канд. техн. наук, старший викладач кафедри управління судном, завідувач лабораторією електронних симуляторів Херсонської державної морської академії, Україна.

Прокопчук Ю. О. - д-р техн. наук, доцент, провідний науковий співробітник відділу системного аналізу та проблем управління, Інститут технічної механіки, Національна академії наук, Україна.

Макарчук Д. В. - канд. техн. наук, старший викладач кафедри управління судном Херсонської державної морської академії, Україна.

\section{АНОТАЦІЯ}

Актуальність. У статті розглядається підхід ідентифікації антиципації як важливої складової процесу прийняття рішень оператора на прикладі капітана далекого плавання в ергатичних системах критичних інфраструктур при управлінні морським транспортом. Розглянутий аспект антиципації операторів $\epsilon$ складною формою людино-машинного взаємодії і вимагає розробки підходів та відповідних інформаційних засобів.

Мета. Підхід щодо розробки засобів грунтується на інформаційному аналізі повного спектра траекторій прийняття рішень операторів в моменти виконання складних багатоетапних дій заснованих на прийнятій стратегії людино-машинної взаємодії. Такий підхід передбачає формування метрики здатної алгоритмічним способом відобразити простір варіантів в умовах комбинаторного передуявлення в термінах геометричної теорії груп на графі Келі.

Метод. В рамках розробки підходу визначена математична модель збору та обробки експериментальних-тальних даних в ході аналізу бази даних навігаційних симуляторів. 3 метою підтвердження прийнятих формально-алгоритмічних підходів проведено імітаційне моделювання що формує траєкторію прийняття рішень оператора в критичних ситуаціях заснованих (C) Nosov P. S., Popovych I. S., Cherniavskyi V. V., Zinchenko S. M., Prokopchuk Y. A., Makarchuk D. V., 2020 DOI 10.15588/1607-3274-2020-3-15 
на трехфакторной моделі ERO-AEA-EAPI. Таким чином алгебраїчне і програмне представлення метричного простору прийняття рішень дозволяє апроксимувати складні людино-машинні взаємодії в умовах невизначеності і отримати підхід трансформації даних в знання про суб'єкта критичної інфраструктури - оператора.

Результати. 3 метою підтвердження доцільності розроблених формально-алгоритмічних підходів був проведений експеримент з використанням навігаційного симулятора Navi Trainer 5000 (NTPRO 5000). В ході експерименту були проаналізовані дані сервера при виконанні однієї з найбільш складних операцій - швартуванні, і сформовані знання про антиципацію операторів у вигляді триангулярних конструктів на квазіізометричному просторі графа Келі. Результати моделювання із застосуванням автоматизованої нейроної мережі дозволили отримати множинну регресію даних і провести аналіз зв'язків незалежних змінних про що свідчать результати діаграм розсіювання і надійності.

Висновки. Формально-алгоритмічні підходи, представлені в дослідженні, в поєднанні з розробленими програмними засобами, підходи перетворення даних у метаданні про антиципацію операторів дозволили класифікувати і визначити індивідуальні стратегії прийняття рішень при управлінні судном що дало змогу прогнозувати ймовірність катастрофічних наслідків. Результативність запропонованого підходу i моделей була успішно обгрунтована за результатами автоматизованої обробки експериментальних даних.

КЛЮЧОВІ СЛОВА: системи підтримки прийняття рішень; системи ідентифікації знань; модель оператора; комп'ютерні навігаційні симулятори; управління ризиками; аналіз людського фактора; автоматизовані системи управління.

\section{УДК 004.942: 316.454 .54}

\section{АВТОМАТИЗИРОВАННАЯ ИДЕНТИФИКАЦИЯ АНТИЦИПАЦИИ ОПЕРАТОРА НА МОРСКОМ ТРАНСПОРТЕ}

(RU)

Носов П. С. - канд. техн. наук, доцент кафедры судовождения и электронных навигационных систем Херсонской государственной морской академии, Украина.

Попович И. С. - д-р наук, профессор кафедры общей и социальной психологии Херсонского государственного университета, Украина.

Чернявский В. В. - д-р наук, профессор, ректор Херсонской государственной морской академии, Украина.

Зинченко С. М. - канд. техн. наук, старший преподаватель кафедры управления судном, заведующий лабораторией электронных симуляторов Херсонской государственной морской академии, Украина.

Прокопчук Ю. А. - д-р техн. наук, доцент, ведущий научный сотрудник отдела системного анализа и проблем управления, Институт технической механики, Национальная академии наук, Украина.

Макарчук Д. В. - канд. техн. наук, дальнего плавания, старший преподаватель кафедры управления судном Херсонской государственной морской академии, Украина.

\section{АННОТАЦИЯ}

Актуальность. В статье рассматриваются подходы идентификации антиципации как важной составляющей процесса принятия решений оператором на примере капитана дальнего плавания в эргатических системах критических инфраструктур при управлении морским транспортом. Рассматриваемый аспект антиципации операторов является сложной формой человеко-машинного взаимодействия и требует разработки информационных подходов и средств.

Цель. Подход к разработке подходов основывается на информационном анализе полного спектра траекторий принятия решений операторов в моменты выполнения сложных многоэтапных действий основанных на принятой стратегии человекомашинного взаимодействия. Такой подход предполагает формирование метрики способной алгоритмическим способом отобразить пространства вариантов, в условиях комбинаторного представления, в терминах геометрической теории групп на графе Кэли.

Метод. В рамках разработки подхода определена математическая модель сбора и обработки экспериментальных данных в ходе анализа базы данных навигационных симуляторов. С целью подтверждения принятых формально-алгоритмических подходов проведено имитационное моделирование формирующее траекторию принятия решений оператора в критических ситуациях основанных на трехфакторной модели ERO-AEA-EAPI. Таким образом алгебраическое и программное представление метрического пространства принятия решений позволяет аппроксимировать сложные человеко-машинные взаимодействия в условиях неопределенности и получить подход трансформации данных в знания о субъекте критической инфраструктуры - операторе.

Результаты. С целью подтверждения целесообразности разработанного подхода и формально-алгоритмических подходов был проведен эксперимент с использованием навигационного симулятора Navi Trainer 5000 (NTPRO 5000). В ходе эксперимента были проанализированы данные сервера в ходе выполнения одной из наиболее сложных операций - швартовки, и сформированные знания об антиципации в виде триангулярных конструктов на квазиизометрическом пространстве графа Кэли. Результаты моделирования с применением автоматизированных нейронных сетей позволили получить множественную регрессию данных и провести анализ связей множества независимых переменных о чем свидетельствуют результаты диаграмм рассеивания и надежности.

Выводы. Формально-алгоритмические подходы, представленные в исследовании, в сочетании с разработанными программными средствами, подходы преобразования данных в знания об антиципации операторов позволили классифицировать и определить индивидуальные стратегии принятия решений при управлении судном и прогнозировать вероятность катастрофических последствий. Результативность предложенного подхода и моделей была успешно обоснована по результатам автоматизированной обработки экспериментальных данных.

КЛЮЧЕВЫЕ СЛОВА: системы поддержки принятия решений; системы идентификации знаний; модель оператора; компьютерные навигационные симуляторы; управление рисками; анализ человеческого фактора; автоматизированные системы управления. 


\section{ЛІТЕРАТУРА / ЛИТЕРАТУРА}

1. Automatic Identification System (AIS): Data Reliability and Human Error Implications / [A. Harati-Mokhtari, A. Wall, P. Brooks et al. ] // Journal of Navigation. - 2007. -Vol. 3, Issue 60. - P. 373-389. DOI:10.1017/S0373463307004298.

2. Be in Command by Knowing These ECDIS Safety Settings. Written by Capt Rajeev Jassal (on August 20), 2016 [Electronic resource]. https://www.myseatime.com/blog/detail/be-in-command-byknowing-these-ecdis-safety-settings.

3. Yurzhenko A. (2019). An E-course based on the LMS Moodle to teach "Maritime English for Professional purpose" / A. Yurzhenko // Information Technologies and Learning Tools. - 2019. - Issue 71. - P. 92. DOI: 10.33407/itlt.v71i3.2512.

4. Improving Accuracy and Reliability in Automatic Ship Motion Control Systems / [S. M. Zinchenko, A. P. Ben, P. S. Nosov et al.] // Radio Electronics, Computer Science, Control. - 2020. - Vol. 2. - P. 183-195.

5. Diagnostic system of perception of navigation danger when implementation complicated maneuvers / [P. S. Nosov, S. M. Zinchenko, I. S. Popovych et al.] // Radio Electronics, Computer Science, Control. - 2020. - Vol. 1. - P. 146-161. DOI: 10.15588/1607-3274-2020-1-15.

6. Development of means for experimental identification of navigator attention in ergatic systems of maritime transport / [P. Nosov, I. Palamarchuk, S. Zinchenko et al.] // Bulletin of University of Karaganda. Technical Physics. - 2020. Vol. 1, Issue 97. - P. 58-69. DOI: 10.31489/2020Ph1/58-69.

7. Geometric group theory. Malyutin, A. (2020) [Electronic resource]. - $\quad$ Access mode: https://www.lektorium.tv/node/32971

8. Research of the factor structure of the model of world view settings at a young age / [O. Kononenko, A. Kononenko, V. Stynska et al.] // Revista Inclusiones. -2020. - Vol. 7. P. 98-116.

9. The value of captains' behavioral choices in the success of the surfclam (spisula solidissima) fishery on the U.S. MidAtlantic Coast: a Model Evaluation / [E. Powell, J. Klinck, D. Munroe et al.] // Journal of Northwest Atlantic Fishery Science. - 2020. - Vol. 47. - P. 1-27. DOI: 10.2960/J.v47.m701.

10. Pinheiro L. Risk Analysis and Management of Moored Ships in Ports / L. Pinheiro, C. Fortes, J. Santos // 37th International Conference on Ocean, Offshore and Arctic Engineering, Madrid, 17-22 June 2018: proceedings. - ASME, 2018. V003T02A057. DOI:10.1115/OMAE2018-78396

11. Chen L. Current problems and risk analysis on high pollution risk operation of ship / L. Chen, C. Rong-chang // 5th International Conference on Transportation Information and Safety (ICTIS). - Liverpool. - 2019. - P. 136-140 DOI:10.1109/ICTIS.2019.8883804.

12. Gluver H. Current practice in risk analysis of ship collisions to bridges / H. Gluver, D. Olsen // Ship Collision Analysis: book. - Copenhagen, 2018. - P. 85-96 DOI:10.1201/9780203739778-9.

13. Lee $\mathrm{H}-\mathrm{W}$. Antiaging strategy considering physiological characteristics / H-W. Lee, H-I. Rhyu // Journal of Exercise Rehabilitation. - 2019. - Vol. 15. - P. 346-350. DOI:10.12965/jer.1938214.107.

14. Yu H. Study on Physiological Characteristics of Emotion / H. Yu, D. Guo // Fifth International Conference on Instrumentation and Measurement, Computer, Communication and Control (IMCCC). - Qinhuangdao. - 2015. - P. 12861289. DOI:10.1109/IMCCC.2015.276.
15. Kurdel P. Computing skills in aviation ergatic systems / P. Kurdel, T. Lazar, J. Labun // 12th International Symposium on Applied Machine Intelligence and Informatics (SAMI): IEEE. - Herl'any. - 2014. - P. 375-379. DOI: 10.1109/SAMI.2014.6822443.

16. Modelización del transporte marítimo de contenedores / [P. Millán, L. Inglada-Pérez, P. Casares et al.] // Estudios de Economía Aplicada. - 2019. - Vol. 36. - P. 675. DOI: 10.25115/eea.v36i3.2548.

17. Marine measurement and real-time control systems with case studies / [M. Ertogan, G. Tayyar, P. Wilson et al.] // Ocean Engineering. - 2018. - Vol. 159. - P. 457-469. DOI: 10.1016/j.oceaneng.2018.02.001.

18. Information Interface of Artificial Intelligence Medical Device Information / [X. Wang, T. Fu, Y. Zhang et al.] // Big Data Analytics for Cyber-Physical System in Smart City. 2020. - Vol. 1117. - P. 1293-1303. DOI: 10.1007/978-98115-2568-1 180.

19. Automatic collision avoidance with multiple targets, including maneuvering ones / [S. M. Zinchenko, P. S. Nosov, V. M. Mateychuk et al.] // Radio Electronics, Computer Science, Control. - 2019. - Vol. 4. - P. 211-221. DOI: 10.15588/1607-3274-2019-4-20.

20. Automatic collision avoidance system with many targets, including maneuvering ones / [S. Zinchenko, P. Nosov, V. Mateichuk et al.] // Bulletin of University of Karaganda. Technical Physics. - 2019. - Vol. 4. - P. 69-79. DOI: 10.31489/2019Ph4/69-79.

21. Action Planning Modulates Peripersonal Space / [I. Patané, L. Cardinali, R. Salemme et al.] // Journal of Cognitive Neuroscience. - 2018. - Vol. 31. - P. 1-14. DOI: $10.1162 /$ jocn a 01349 .

22. Vişan, M. Data Analysis in Setting Action Plans of Telecom Operators / M. Vişan, A. Ionita, F. Filip // Challenges and Applications. Studies in Computational Intelligence. Springer. - 2020. - Vol. 869. DOI: 10.1007/978-3-03039250-5 6.

23. Malyutin A. Pretrees and Arborescent Convexities / A. Malyutin // Journal of Mathematical Sciences. - 2016. Vol. 212. - P. 566-576. DOI: 10.1007/s10958-016-2689-1.

24. Gromov M. Hyperbolic groups. Essays in group theory / Gromov M. (S. M. Gersten, ed.) // MSRI Publ. 8. Springer-Verlag, 1987. - P. 75-263.

25. Rips E. Structure and rigidity in hyperbolic groups / E. Rips, Z. Sela. - Geom. Funct. Anal. - 1994. - No. 3. - P. 337371.

26. Prokopchuk Y.A. Sketch of the Formal Theory of Creativity / Y. A. Prokopchuk. - Dnepr : PSACEA Press, 2017. $452 \mathrm{p}$.

27. Combining Takt and Deming Cycles at Operator Level Practical Study / [J. Lerche, H. Neve, S. Wandahl et al.] // The 10th International Conference on Engineering, Project, and Production Management, January 2020. - P. 623-632.

28. Method of large-scale signals transformation for diagnosis in neural network models / [I. O. Lymariev, S. A. Subbotin, A. A. Oliinyk et al.] // Radio Electronics, Computer Science, Control. - 2018. - Vol. 4. - P. 121-134. DOI: 10.15588/1607-3274-2018-4-11

29. Subbotin S. A. Methods of synthesis of models of quantitative dependencies in the basis of trees of regression, realizing cluster - regression approximation by precedents / S. A. Subbotin // Radio Electronics, Computer Science, Control. - 2019. - Vol. 3. - P. 76-85. DOI: 10.15588/16073274-2019-3-9 